\title{
AZ EGYENESFOGÚ METSZŐKERÉK SZERSZÁMKAPCSOLÓSZÖGÉNEK OPTIMÁLÁSA
}

\author{
Máté Márton
}

A mets7ỏkcrckcket a šakirodalom olyan fogaskerekekként tárgyalja, amelyek profileltolása egyenesen arányosan csökken a kerék alapsíkjától számított távolsággal. Habár a szerszám fogának oldalfelületei cvolvens csavarfelületek, a vágóélek vetülete az alapsíkra a tökéletes evolvenstől eltér. A klasszikus elınélet szerint gyártott szerszám kapcsolószögét egyszerũ képlettel számítják [1],amely a fogszámot nem veszi figyelembe. így a vágóél vetületének görbületét sem. A fellépỏ profilhibák csak alacsony értékủ hoinlokszög mellett maradnak a tűrésmezōn belül. A jelen dolgozatban egy olyan számítási módszer van ismertetve, amely a szerszámkapcsolószög meghatározását a vágóél vetülete mentén észlelhető átlagos négyzetes profileltérés értékének minimálásán alapszik. A módszer alkalmazásásval elérhetõ a csúcshomlokszög megkétszerezése, és a profilhibák sem haladják meg a megengedelt értéket.

\section{$\Lambda$ vágóéi vetuiletének parametrikus egyenletei.}

A metszökerék vágóélei a szerszám forgácsolómozgása következtében egyenesfogú fogaskereket burkolnak. Ennek a keréknek a fogprofilja azonos a vágóél egy tetszöleges, szerszámtengelyre meröleges sikra képzett vetületével. Ahhoz, hogy a metszökerék tökéletes evolvensprofilú kereket burkoljon, szükséges, hogy a fömozgásban leírt kerék fogprofilja is evolvens legyen. Ez a feltétel, amint a szakirodalomból kitünik, nem teljesül. Ennek következtében a gyártott kerék profilhibával készül. Általánosan elfogadott vélemény az, hogy az előbb emlitett szerszámhiba hasznos, mivel a vágóél vetülete kivülröl érinti a tökéletes evolvenst ennek osztókörön illeszkedő pontjában és ennek következtẻben a fogfej- illetve fogláblenyesést is elvégzi. Ahhoz, hogy a profilhiba a türésmezön belül maradjon, a szerszámot a gyakorlatban általában $5^{\circ}$ - os fejhomlokszöggel gyártják. Ez az érték a vágóél mentén $2^{\circ}$ - nál kisebb homlokszöget jelent, ami a forgácsolás szempontjából kedvezötlen [2].

A szerszám forgácsképzésének javitása a homlokszög növelésével válik lehetségessé. A profilhiba csökkentése két módon lehetséges: az ősszerszám egyenes profiljának módositása úgy, hogy a vágóél vetülete tökéletes evolvens legyen, vagy pedig az egyenes vonalú ősszerszámprofil megtartása a szerszámkapcsolószög módositásával. Ez utóbbi változat technológiai megoldása egyszerübb, azonban a profilhiba megmarad. A vágóél vetülete ennek a szögnek a függvényében változik. A burkolt profil parametrikus egyenleteit célszerü egyszerü geometriai megfigyelések alapján levezetni. A vágóél a szerszám fogának evolvens csavarfelületének és a homlokfelület nek metszete.Az utóbbi egyenes 
körkúp, melynek tengelye a szerszám tengelyével egybeesö. İgy a homlokfelület metszete egy a szerszám tengelyére meröleges síksereggel egyenesen arányosan csökkenö sugarú körsereg, melynek sugarát a vágóél paramétereként tekintünk. Az 1 . sz. ábra alapján, a tetszöleges $X-X$ sikban a profileltolás értéke

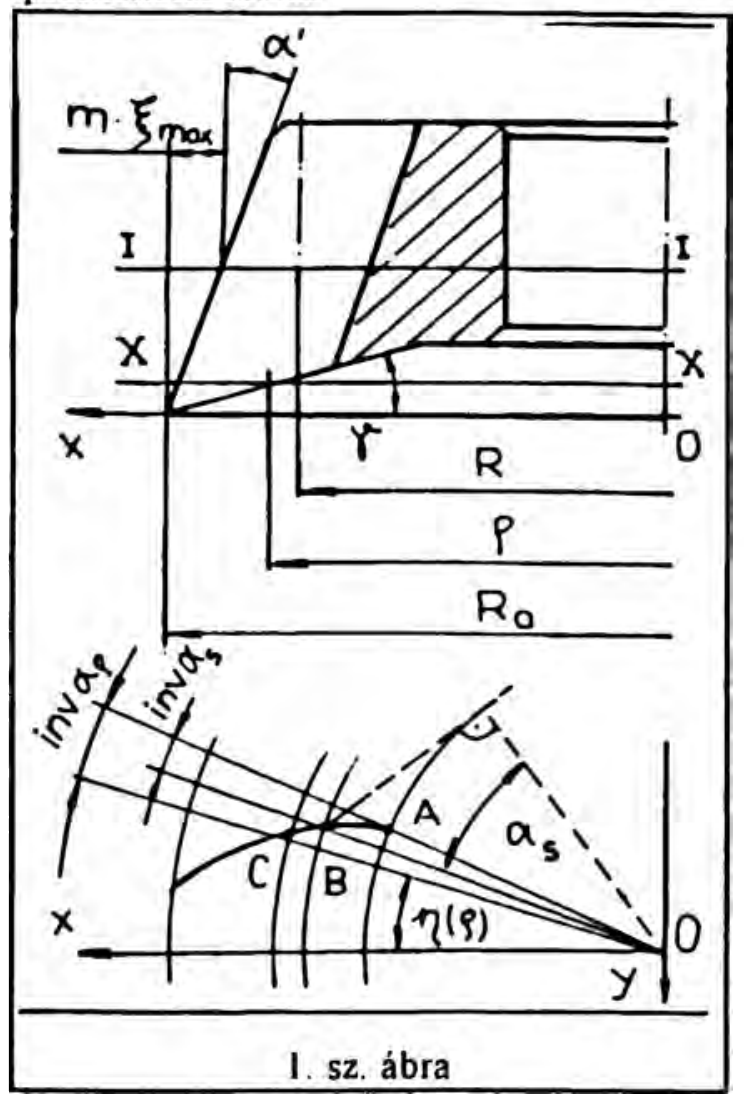

$$
\zeta(\rho)=\xi_{\max }-\frac{\mathbf{R}_{\mathrm{a}}-\rho}{\mathbf{m}} \operatorname{tg} \gamma \operatorname{tg} \alpha^{\prime}
$$

Az evolvenstrigonometria alapegyenletéböl a vágóél $X-X$ sikjában levő pontja vetületéhez húzott sugár és az $0 \mathrm{x}$ tengely által bezárt szög a következő képletrend-szerrel számitható:

$$
\left\{\begin{array}{l}
\eta(\rho)=\operatorname{mv} \alpha_{.}+\frac{s(\rho)}{m z}-\operatorname{inv} \alpha_{f} \\
s(\rho)=\frac{\pi m}{2}+2 m \xi(\rho) \operatorname{tg} \alpha_{s} \\
\operatorname{inv} \alpha_{f}=\frac{\sqrt{\rho^{2}-R_{b}^{2}}}{R_{b}}-\arccos \frac{R_{b}}{\rho}
\end{array}\right.
$$

Az (1) és (2) képletek alapján a szerszámél vetületének (a továbbiakban a burkolt görbe) egyenletei a következöek:

$$
\left\{\begin{array}{l}
x(\rho)=\rho \cos \eta(\rho) \\
y(\rho)=\rho \sin \eta(\rho)
\end{array}\right.
$$

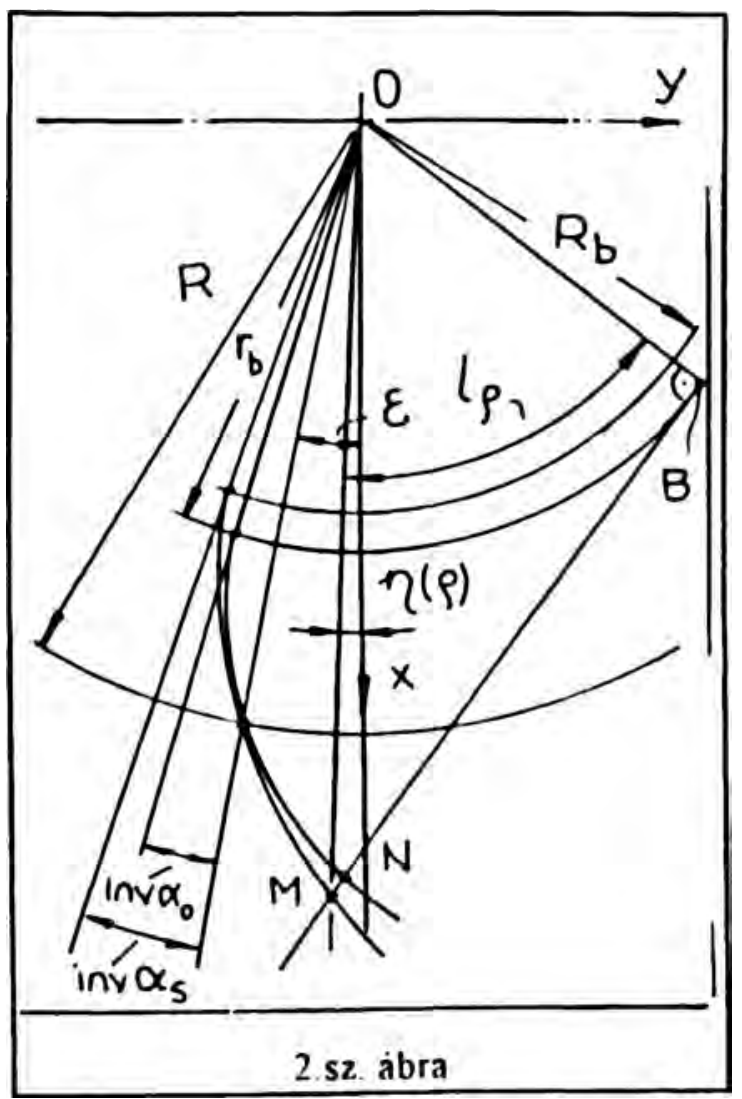

\section{A profilhiba számítása.}

Profilhiba alatt a burkolt görbe futópontja és az ezt érintö tökéletes evolvensgörbe az evolvensre normálirányban mért távolságot értjük. Megjegyezendö, hogy az elméleti evolvenssel kapcsolódó lécprofil szöge a megmunkálandó fogaskerék lécprofilszögével megegyezö.

Amint a 2.sz. ábrából kitünik, a profilhiba a BM és BN szakaszok különbsége. A BM szakasz hossza az OMB derékszögü háromszögböl Pithagorasz tételével számítható. A BN szakasz hossza az AB köriv hosszával megegyező. A viszonyitó evolvens a burkolt profilt az osztókörön érinti. $A z$ érintkezési pont $O x$ tengelyhez viszonyitott helyzetszöge a (2) képletekkel számitható, $\rho=R$ értékre. A BM és BN szakaszok hossza a burkolt profil futópontjának sugarától függően a következőek: 


$$
\left\{\begin{array}{l}
B M=\sqrt{\rho^{2}-r_{b}^{2}} \\
B N=r_{b}\left[i n v \alpha_{0}+\eta(R)-\eta(\rho)+I(\rho)\right]
\end{array}\right.
$$

A számitások elvégzése után a profilhiba kifejezése a következö alakot ölti:

$$
\begin{aligned}
\Delta(\rho)= & \sqrt{\rho_{2}-r_{b}^{2}}-r_{b}\left(\operatorname{inv} \alpha_{0}+2 \frac{R-\rho}{m z} \operatorname{tg} \alpha^{\prime} \operatorname{tg} \gamma \operatorname{tg} \alpha_{s}+\arccos \frac{r_{b}}{\rho}-\arccos \frac{R_{2}}{\rho}+\arccos \frac{R_{b}}{R_{H}}+\right. \\
& \left.+\frac{\sqrt{\rho^{2}-R_{b}^{2}}}{R_{b}} \frac{\sqrt{R^{2}-R_{b}^{2}}}{R_{b}}\right)
\end{aligned}
$$

$A z(5)$ kifejezésböl látszik, hogy a profilhiba az $\alpha_{\mathrm{s}}$ szerszámkapcsolószög és a $\rho$ sugár függvénye.

\section{^ szerszámkapcsolószög optimálása.}

A szerszám kapcsolószög optimális értékének azt az értéket tekintjük, amelyre a $\Delta(\rho)$ profilhiba négyzetes középértéke minimális lesz. Mivel a $\Delta(\rho)$ függvény $\rho$ szerint az $\left[R_{i}, R_{a}\right]$ intervallumon folytonos, a $\Delta(\rho)$ négyzetes középértékét az alábbi képlet adja:

$$
\sqrt{\overline{\Delta^{2}}}=\sqrt{\frac{1}{R_{0}-R_{1}} \int_{R_{1}}^{R_{0}} \Delta^{2}(\rho) d \rho}
$$

A (6) képlet egy olyan Riemann összeget jelöl, melynek minden tagja pozitiv, és ezek szerint ennek a helyi szélsőèrték - amennyiben létezik- csak minimum lehet. İgy a kapcsolószög optimum értéke a

$$
\frac{\mathrm{d}}{\mathrm{d} \alpha .}\left(\sqrt{\overline{\bar{\Delta}^{2}}}\right)=\mathbf{0}
$$

egyenlet megoldása $\alpha_{\mathrm{S}}$-re. A deriválás elvégzése után a (7) egyenlet alakja a következö:

$$
\int_{\mathbf{R}_{1}}^{\mathbf{R}} \Delta(\rho) \frac{d(\Delta(\rho))}{d \alpha_{3}} d \rho=0
$$

ahol a profilhibafüggvény $\alpha_{\mathrm{S}}$ szerinti deriváltja

$$
\frac{d(\Delta(\rho))}{d \alpha_{,}} \equiv \Delta_{=1}^{\prime}=-\frac{r_{b}}{R}\left((R-\rho) \operatorname{tg} \alpha^{\prime} \operatorname{tg} \gamma \frac{1}{\cos ^{2} \alpha_{0}}+\frac{\sin \left(\alpha_{1}\right.}{\cos ^{2} \alpha_{1}}\left(\sqrt{\rho^{2}-K^{2} \cos ^{2} \alpha_{z}}-\sqrt{R^{2}-R^{2} \cos ^{2} \alpha_{1}}\right)\right)
$$

képlettel számítható.

A (8) egyenlet integrálása igen bonyolult, $\alpha_{\mathrm{S}}$-ben transzcendens egyenlethez vezet, amelynek megoldása numerikus módszerek alkalmazásával lehetséges. A megoldás egyszerüsitése végett a (8) egyenlet baloldalát a Simpson képlettel közelitjük, mely viszonylag kisszámú csomópontra felirva is elégségesen pontos közelitést ad. Így a szerszámkapcsolószög optimális értéke az

$$
\sum_{j=0}^{20}\left(3-(-1)^{j}\right) \Delta\left(\rho_{j}\right) \Delta_{\alpha_{1}}^{\prime}\left(\rho_{j}\right)-\left(\Delta\left(\rho_{0}\right) \Delta_{\alpha_{1}}^{\prime}\left(\rho_{0}\right)+\Delta\left(p_{20}\right) \Delta_{\alpha_{1}}^{\prime}\left(\rho_{20}\right)\right)=0
$$

egyenlet gyöke, a $\rho_{\mathrm{j}}$ értékek pedig az $\left[R_{\mathbf{i}}, R_{\mathbf{a}}\right]$ intervallum 21 csomópontja. 


\section{Numerikus kiértékelés.}

A felállitott elmélet hatékonysága egy $z=40$ fogú ès $m=5 \mathrm{~mm}$ modulú metszökerék kapcsolószögének a klasszikus és az elöbbiekben vázolt módszerrel való számításának összehasonlitásával válik érzékelhetővé. A klasszikus számitási módszer alkalmazásakor $\gamma=6^{\circ}-\mathrm{os}$, a leirt módszer esetében pedig $\gamma=12^{\circ}$-os homloszöget tekintünk. A 3. sz. ábrán a profilhibák változása látható a $\rho$ paraméter függvényében.

A klasszikus módszerrel számított kapcsolószögü szerszám profilhibája gyakorlatilag a fog hegye fele növekvő, ezért elönytelen. Észlelhető, hogy a maximális hibaértèk kb $7 \mu \mathrm{m}$ (felső görbe). Ezzel szemben az optimált kapcsolószögü szerszám profilhibaeloszlása kedvezőbb, mivel a fogfejen illetve a foglábon közel azonos értéküek, és legnagyobb abszolút érték kb $4 \mu \mathrm{m}$ (alsó görbe). A (10) egyenlet megoldása $10 \mathrm{e}-7$ nagyságrendü hibával történt.

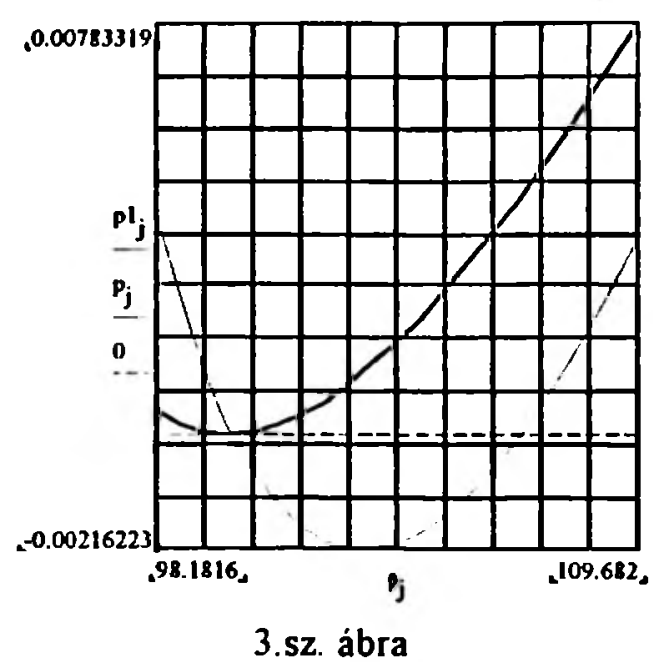

\section{IRODALOM}

1.HOLLANDA,D., Așchiere şi scule aşchietoare, Institutul de İnvăfămînt Superior din Tîrgu Mureş 1982.

2.BOUZAKIS,K.,Erhöhung der Wirtschaftlichkeit beim Wălzstossen durch Optimierung der Zerspanprozesses und der Werkzeugauslegung, R.T.W.A. Aachen, 1976

Máté Márton egyetemi adjunktus

Marosvásárhelyi Egyetem, N Iorga u., 1. sz., 4300 Marosvásárhely. 